\title{
Job Satisfaction in Teachers: Theoretical and Methodological Proposal
}

\author{
Rosalba Treviño Reyes \\ Autonomous University of Nuevo Leon \\ Adriana Segovia Romo \\ Autonomous University of Nuevo Leon \\ Elías Alvarado Lagunas \\ Autonomous University of Nuevo Leon \\ Pablo Guerra Rodríguez \\ Autonomous University of Nuevo Leon
}

This paper analyzes the structural empowerment, psychological empowerment, and job satisfaction of teachers from public institutions in middle higher education in Mexico. The theoretical review covers the approach to the problem and discusses the variables and graphic models used in the study. It also presents the proposed hypotheses and the main methodological challenges encountered. It considers the importance of studying the attitudes and behaviors that influence the organizational behavior of the workforce. It focuses on a geographic area not covered in previous research.

Keywords: Structural Empowerment, Psychological Empowerment, Job Satisfaction, Teachers

\section{INTRODUCTION}

Faced with a changing world, organizations consider the attitudes and behaviors of their workers as the most important resource in achieving success. Work conditions vary diversely in companies, institutions and organizations. But if a company aspires for better job performance, an increase in productivity and good welfare for employees, it is important to consider aspects of organizational behavior that could influence the workforce.

Structural and psychological empowerment points out that an empowered, committed and satisfied employee, both as an individual or part of a group, may exhibit greater performance than that obtained through extrinsic motivators such as remunerations (Marvel, Rodríguez and Núñez, 2011).

The majority of past investigations about this topic dealt primarily with welfare service workers such as nurses. However, there is still an epistemological vacuum in the field of teaching, which is why it is necessary to study it. 
Currently, the main labor problems are in aspects of organizational behavior of employees, such as job satisfaction (Chiang, Núñez and Huerta, 2007), organizational commitment (Barraza, Acosta and Ledesma, 2008), burnout (Partida, Blanco, Osorio and Jardines, 2013), among others. These factors generate explicit and implicit costs that impact performance, productivity and work climate (Baños, 2009).

Randstad's quarterly survey showed that in Mexico, $80 \%$ of workers say they are satisfied with their job, their position and their employer. This represents a high percentage compared to other countries, such as Japan, where only 4 of every 10 workers said they were satisfied in their work centers. It emphasizes that job satisfaction is one of the main drivers of productivity and efficiency at work, which ultimately increases the profitability of companies (La Jornada, 2014).

On the other hand, according to Randstad Workmonitor, the younger the age, the higher the level of job satisfaction. This is a trend that has remained in recent years. The rate of job satisfaction among those under 25 has increased consecutively since 2015 (Betisweb, 2016). In addition, employees with higher education register a greater degree of job satisfaction, with $81 \%$ (El Economista, 2016).

With this perspective, this research will be carried out in educational institutions of the upper middle level of the public system in the citrus region of Nuevo Leon in Mexico (integrated by the municipalities of Linares, Hualahuises, Montemorelos, Allende, Rayones and General Teran). This is a geographical area that experienced a significant economic, organizational, commercial, educational and cultural development in recent decades. It lies outside the metropolitan area of Monterrey, which is not yet covered by the revised literature, considering the transcendental aspects of human resources management, the organizational structure and the human behavior factors.

One of the organizational changes that requires focus in the study of Human Resources is the education system. Barraza et al. (2008) explain that one of the great challenges that institutions of middle higher education currently face is the need to create useful strategies through which teachers can become committed to organizational objectives and integrated into institutional projects. Under this premise, it is understood that if teachers are highly satisfied and involved in the organization in which they work, they will be more likely to remain in it and exhibit better job performance (Barraza et al., 2008).

\section{Research Question}

What are the relationships between structural empowerment and psychological empowerment, and this in turn with job satisfaction in teachers of public institutions of middle higher education in the citrus region of the state of Nuevo Leon?

\section{General Objective}

Determine the relationships between structural empowerment and psychological empowerment, and this in turn with job satisfaction in teachers of public institutions of middle higher education in the citrus region of the state of Nuevo Leon.

\section{Hypothesis}

H1. Structural empowerment is positively related to psychological empowerment in teachers of public institutions of middle higher education.

H2. Psychological empowerment is positively related to job satisfaction in teachers of public institutions of middle higher education.

Using Creswell's criteria (2015), this research will contribute to knowledge in various theoretical gaps since authors have not studied some proposed variables. Few scientific studies have been found in Mexico, and in particular in Nuevo León, where it is probable that the model proposed in this study has not been specifically studied before. The use of structural equations has not been found in the statistical analysis of the mentioned model as well. It will cover a geographic area that was not covered in the 
researches that are mentioned in the literature review. The study will generate valid and reliable knowledge, being a valuable contribution to the quality, efficiency and effectiveness of the teachers' performance, reflected in the psychological well-being and organizational behavior of employees in the institutions covered by this study.

\section{THEORETICAL FRAMEWORK}

The area presents the description of the variables that the study will focus on. It also presents its relationships and the main causes of its investigation.

\section{Dependent Variable. Job Satisfaction}

Job satisfaction is important in any kind of work, not only in terms of desirable welfare of people, but also in terms of productivity and quality of work. Boada and Tous (1993) explain that it has become a central problem for the research of the organization and is one of the areas of quality of work life that has attracted most interest. Several authors have studied the concept for decades, allowing a meaningful evaluation of it. Hackman and Oldham (1975) define job satisfaction as a measure of the degree to which workers feel happy or satisfied with their jobs. Locke (1976) refers to it as a positive and pleasant emotional state resulting from the personal assessment that the individual makes about his work and about the experience acquired in it.

According to Harpaz (1983), there is no unanimously accepted definition of the concept of job satisfaction, it also indicates that people who work usually develop a set of attitudes that can be described by the general term of job satisfaction. Garmendia and Parra (1993) associate it with the feeling of wellbeing derived from covering the needs of a certain level through the results (considered acceptable) obtained as a reward for the work done, and Spector (1997) defines it as a feeling or attitude towards the work as a whole and its different aspects.

On the other hand, Schultz (1995, cited in Ramírez and Benítez, 2012) defines job satisfaction as the attitude of the person towards his work (what he thinks about it, whether he is happy or not with his job) and assumes a set of attitudes or feelings about oneself. Blum and Taylor (1999) agree that job satisfaction is the result of various attitudes that employees have related to specific factors such as wages, supervision, constancy of employment, working conditions, opportunities for promotion, recognition of the capacity, the fair evaluation of the work, the social relations in the employment, the fast resolution of the reasons of complaint, the fair treatment by the employers and others similar.

Davis and Newstrom (2007) define job satisfaction as a set of favorable and unfavorable feelings through which employees perceive their work. Job satisfaction is changing because satisfactory feelings grow and decrease as the reasons for achievement are covered, so that the initial intensities are

complemented by the behaviors performed. For Shahzad, Hussain, Bashir, Chishti and Nasir (2011) it is the difference between what the employee thinks he deserves and what he really gets for his work. It is a response of the attitude of the employees toward the organization and affects both the decision to remain in the company as the amount of effort applied in the performance of the position (Ghazzawi and Smith, 2009).

Sarwar and Khalid (2011) define it as the pleasant emotional state of an employee when considering his obligations, his supervisor and the organization itself. They identified 6 factors that influence job satisfaction: opportunity, stress, work standards, proper authority, fair rewards, and leadership.

There is still a general assumption that compensation is the most important element in terms of the job satisfaction factor. A survey conducted by the Society of Human Resource Management (SHRM) based in Alexandria, Virginia, points out that workers' main concerns are job security and benefits (Gibson et al., 2013).

Specifically, in the area of education, Ramírez and Benítez (2012) state that educational institutions seek systems, methods, and procedures that help improve their operating conditions from within, so that there is job satisfaction in workers. There is also a positive impact on the quality of the service. 
After the above definitions have been reviewed, job satisfaction will be defined as a positive and pleasant emotional state resulting from the individual's assessment of their work and the experience acquired in it, considering their obligations, their supervisor and the organization itself (Locke, 1976; Sarwar and Khalid, 2011).

\section{Independent Variable. Structural Empowerment}

"Empowerment" is a term of Anglo-Saxon origin, but in Castilian there are some words like empowerment that attempt to define it in that language. Disciplines such as Psychology, Education, and Social Work have proposed another point of view of empowerment, emphasizing the development of the well-being of the person (Rico-Picó et al., 2016). Empowerment conjures the notion of people who have control over themselves and their environments and rise to higher levels of achievement and personal satisfaction. There are two types of empowerment: structural and psychological (Jáimez and Díaz, 2011).

Kanter $(1977,1993)$ is the first to develop the theory of structural empowerment. According to the literature reviewed, it is defined as a set of activities and practices carried out by management that give power, control and authority to their subordinates, granting them access to information, resources, support and opportunities to learn and develop (Chen and Chen, 2008; Kanter, 1993).

Analyzing the relations of structural empowerment with other variables, it is observed that most of the authors relate it to the psychological empowerment variable, using the latter as a mediator between one or more attitudinal variables of the employees, such as job satisfaction, organizational commitment, or burnout.

O'Brien (2010) found a statistically significant positive correlation between structural empowerment and psychological empowerment $(\mathrm{r}=.59, \mathrm{p}<.01)$ in a sample of 233 nursing professionals working in hemodialysis units, using a design of correlational investigation. Another study that empirically supports this relationship in nurses is that of Laschinger, Finegan, Shamian and Wilk's (2003).

In addition, studies were found that relate structural empowerment with psychological empowerment in employees of other companies (Corsun and Enz, 1999; Ergenli, Ari and Metin, 2007; Peterson and Speer, 2000). Corsun and Enz (1999) investigated the effect of the dimension of support relationships based on the work environment in the psychological empowerment of service workers.

Jáimez and Díaz (2011) analyzed the relationship of empowerment (structural and psychological) with the three dimensions of organizational commitment according to the multidimensional model of Meyer and Allen (1991). These are labor well-being, the work environment, and the intention of workers to leave, noting that structural empowerment acts as a predictor of psychological empowerment $(\mathrm{B}=$ $0.618, \mathrm{sig}=0.00, \mathrm{p}<.001)$.

\section{Mediating Variable. Psychological Empowerment}

According to Le Bossé and Dufort (2002), in the English language the word empowerment is a common term that can be worked in multiple contexts to signify a positive use of power. Conger and Kanungo (1988) propose that empowerment should be considered as a provocative element to stimulate workers, rather than a simple delegation of power, understanding that empowerment implies creating the conditions that allow increasing motivation for the execution of tasks through the development of a strong sense of personal effectiveness.

Psychological empowerment is defined as the increase of intrinsic motivation in the performance of a function based on four concepts: meaning of the task, competence, self-determination and impact (Thomas and Velthouse, 1990). These guide the individual's approach towards the performance of his or her function (Spreitzer, 1995), emphasizing that psychological empowerment is not a characteristic of personality. Rather, it is a set of cognitions defined based on a certain work context (Segovia, 2014).

Psychological empowerment will be used as a mediating variable between structural empowerment and job satisfaction. It is an intervening variable that affects the relationship between the two variables. In this case, two variables (the independent variable and the potentially mediating variable) influence the dependent variable (Baron and Kenny, 1986; Hayes, 2013). 
When reviewing the relationships in empirical studies of this variable, it was found that Rico-Pico et al. (2016) tried to verify how psychological empowerment, job satisfaction and job identification interact by selecting a sample of different work groups: teachers, health workers and state security bodies. In this study it was found that there is a relationship between the levels of empowerment and satisfaction $(r=$ $.477, p=.007)$ and between empowerment and identification $(r=.644, p=.000)$. However, the study gives no significant relationship between identification and satisfaction $(r=.296, p=.106)$ (Rico-Picó et al., 2016).

On the other hand, the correlation between job satisfaction and empowerment is significant and positive, as already shown in several studies (Seibert et al., 2011; Chang et al., 2010). This may be due, according to various authors, to the fact that job satisfaction depends on the need for development in the position and experiences of autonomy at work (Deci and Ryan, 1985; Hackman and Oldham, 1975; Pearson and Moomaw, 2005). That is, for there to be job satisfaction, several components, which are also central to psychological empowerment, are necessary. Therefore, feeling empowered can act as a mediator by being formed by the cognitions referring to the evaluation of key experiences so that satisfaction occurs in the workplace (Wang and Lee, 2009).

In summary, the studies described provide empirical support for the hypotheses, especially those investigated by nurses working in hospitals. However, literature on this subject that pertain to teachers is scarce and not specific. This is why it is necessary to prove these relationships with other organizational populations, such as the case of teachers of middle higher education. In addition, the existence of the relationship of structural empowerment with psychological empowerment has been verified; but scarcely with job satisfaction, so the following model of cause and effect is proposed (figure 1):

\section{FIGURE 1 \\ PROPOSED GRAPH MODEL}

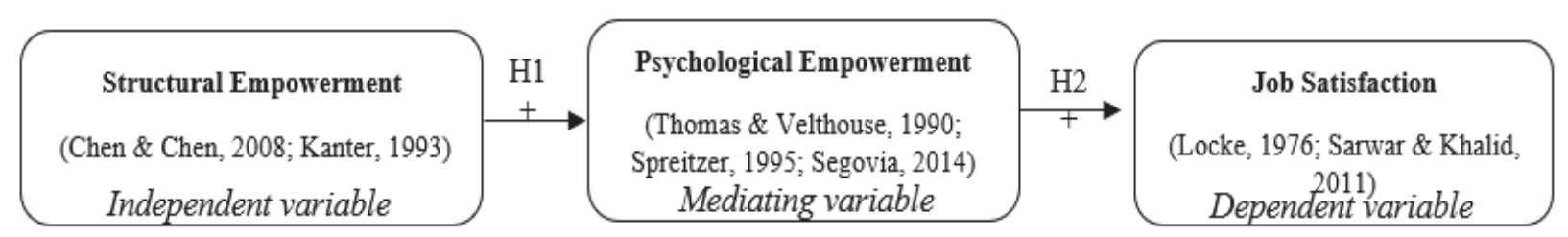

Source: Own elaboration

\section{METHODOLOGY}

The study will be carried out using a quantitative approach, correlational, explanatory scope, nonexperimental, transversal or transectional design. The population of the study includes teachers of a public educational institution of upper middle school who are over 21 years of age, of minimum schooling, basic or fee.

According to the SECTUR (2017), there are 15,206 teachers from public institutions of middle higher education in the State of Nuevo León, which is the general universe. 296 teachers from this group are located in the citrus region, which represents the population subject of the study (UANL, 2018). Through the procedures performed (Rositas and Mendoza, 2009) a sample size "n" of 167 elements is obtained. A non-probabilistic sampling by quotas will be used (Rabolini, 2009), due to the availability of teachers to be surveyed.

A questionnaire will be applied as a data collection tool, in which scales previously validated for the variables will be used and items that better adapt to the context to be studied will be used (Hernández et al., 2016). It will be based on The Conditions of Work Effectiveness Questionnaire (CWEQ-II) (Laschinger, 1996, cited in O'Brien, 2010), The Psychological Empowerment Scale (Spreitzer, 1995, cited in O'Brien, 2010) and the Satisfaction Questionnaire Labor S20 / 23 of Meliá and Peiró (1998). 
This questionnaire will be physical and self-administered by the teachers themselves, trusting in their professionalism, responsibility and commitment. Demographic data will be included for the identification of participating teachers (Vega and Zavala, 2004, cited in Segovia, 2014), using the Likert scale of 7 points (Sánchez, 1998). A survey originally of 30 questions (items) based on the revised theoretical framework was divided into 3 sections that measure each of the variables. The necessary questions (items) are chosen with consideration of the content validity by 10 experts in the area (Mendoza and Garza, 2009).

A certain number of teachers will participate in the pilot study. They are selected with no particular sampling criteria beyond simply meeting the necessary criteria to be able to participate in the study as previously defined. Based on the type of research proposed, the multivariable linear regression model or the structural equation model (SEM) will be chosen, using the SmartPLS 3.0 M3 by Hair et al. (2017), according to the results of the pilot test analysis.

\section{CONCLUSIONS}

In this paper we reviewed the different theories related to the study and included applied definitions by variable (what), empirical relations of previous research (how), conclusions regarding the coverage of these variables in the proposed model (why), and research in the context of teachers of public institutions of middle higher education (who, where and when) (Whetten, 1989). The vacuum or lack of studies in the Mexican context aimed at teachers on the variables investigated is verified (Creswell, 2015). The theoretical section is concluded with the proposed graphic model and the research hypotheses.

The research focuses on high school teachers, since it is a field that has not been studied empirically (Barraza, 2008). It is important to identify the degree of commitment of the teaching staff and look for strategies that contribute to increase it (Padilla et al., 2008).

Emphasis was placed on the study of empowerment, one of the terms that have been analyzed from various fields such as Sociology, Education, Psychology, Social Work, and Organizational Behavior. Although it emerged in the 60 's, it expanded a decade later with Kanter (1977) who introduced it into the workplace. The concept admits a double reading: the psychological sense of personal control (psychological empowerment) and its social influence (structural empowerment).

Kanter $(1977,1993)$ began with his theory of structural empowerment where it is essential that the organization gives employees access to information, resources, support and opportunities. Later, Conger and Kanungo (1988) consider it a construct with its roots on the variables power and control, being able to visualize itself in a relational or motivational way - being a provocative element to stimulate the workers, rather than a delegation of power, increasing their motivation through a strong sense of personal efficacy.

Later, his study emerges from the individual level with Thomas and Velthouse (1990), who explain it as an increase in intrinsic motivation in the performance of the function based on four concepts: meaning, competence, self-determination and impact. While Spreitzer (1995) defines it as an internal motivation that occurs in four types of cognitions that guide the individual's approach towards the performance of their function.

Within the organizational plane, Chen and Chen (2008) explain the structural empowerment carried out by the leadership by giving power, control, and authority to subordinates. Several authors relate it empirically with psychological empowerment (Corsun and Enz, 1999; Ergenli, Ari and Metin, 2007; Peterson and Speer, 2000; O'Brien, 2010; Jáimez and Díaz, 2011).

In addition to this, Rico-Picó et al. (2016) investigated how psychological empowerment, job satisfaction and work identification interact, proving a positive, significant relationship between satisfaction-empowerment, coinciding with several previous studies (Seibert et al., 2011; Chang et al., 2010), as a primary cause, according to various authors, that job satisfaction depends on the significance, need for development in the position and experiences of autonomy at work (Deci and Ryan, 1985, Hackman and Oldham, 1975, Pearson and Moomaw, 2005 ). 
Although the literature found shows incipient features of correlations between psychological empowerment and job satisfaction, it was not possible to find a relationship between the latter and structural empowerment. Therefore, the importance of landing the study of these variables in a joint way in the teaching context, where the work that this implies goes beyond the monetary aspect, being essential to the degree of satisfaction and well-being that teachers have in their institutions and the way they are supported.

In accordance with the theoretical review, the knowledge gaps considered and the methodological challenges it represents, the research model is proposed where the relationships between structural empowerment as an independent variable, psychological empowerment as a mediating variable and labor satisfaction as dependent variable in teachers of public institutions of upper middle level in the citrus region of the state of Nuevo León.

The application of questionnaires, and the analysis and interpretation of the results of the complete future research work, will allow these educational institutions to implement strategies that promote job satisfaction of teachers, in favor of the quality, efficiency and effectiveness of their performance, in turn reflected in students, generating higher rates of terminal efficiency and reducing the rates of failure and dropout.

Finally, the results and conclusions that continue to the field research of this study will be reflected in future work.

\section{REFERENCES}

Baños, A. (2009). Evita la Fuga de Talento. México: Consultorio - Recursos Humanos. Entrepreneur.

Baron, R. M. \& Kenny, D. A. (1986). The moderator-mediator variable distinction in social psychological research: Conceptual, strategic and statistical considerations. Journal of Personality and Social Psychology, 51, 1173-1182.

Barraza, A. (2008). Compromiso organizacional docente. Un estudio exploratorio. Avances en Supervisión Educativa, 8, Asociación de Inspectores de Educación en España.

Barraza, M. A., Acosta CH. M. \& Ledesma, M. Z. E. (2008). Compromiso organizacional de los docentes de una institución de Educación Media Superior. Retrieved from http://www.comie.org.mx/congreso/memoriaelectronica /v10/pdf/area_tematica_16/ponencias/0414-F.pdf

Betisweb (2016). Los menores $\bar{d} e 25$ años que tienen empleo son los más satisfechos con su trabajo. Retrieved from http://www.betisweb.com/otros-temas/179468-los-menores-de-25-anos-quetienen-empleo-son-los-mas-satisfechos-con-su-trabajo.html\#ixzz4PefeWv00

Blum, M., \& Taylor, J. (1999). Psicología industrial sus fundamentos teóricos y sociales. México: Trillas.

Boada, J., \& Tous, J. (1993). Escalas de satisfacción laboral: Una perspectiva dimensional. Revista de Psicología, 15(2), 151-166.

Chang, L., Shih, C. \& Lin, S. (2010). The mediating role of psychological empowerment on job satisfaction and organizational commitment for school health nurses: A cross-sectional questionnaire survey. International Journal of Nursing Studies, 47(4), 427-433.

Chen, H. \& Chen, Y. (2008). The impact of Work Redesign and Psychological Empowerment on Organizational Commitment in a Changing Environment: An Example from Taiwan's StateOwned Enterprises. Public Personnel Management, 37, 279-302.

Chiang, M. M., Núñez, A., \& Huerta, P. C. (2007). Relación del clima organizacional y la satisfacción laboral con los resultados, en grupos de docentes de instituciones de educación superior. Revista Icade. Revista de las Facultades de Derecho y Ciencias Económicas y Empresariales, 8(72), 4974.

Conger, J. \& Kanungo, R. (1988). The empowerment process: Integrating theory and practice. Academy of Management Review, 13(3), 471-482.

Corsun, D. \& Enz, C. (1999). Predicting psychological empowerment among service workers: the effect of support-based relationships. Human Relations, 53(2), 205- 224. 
Creswell, J. W. (2015). Research Design: Qualitative, quantitative, and mixed method approaches, 4th. Edition. Thousand Oaks: Sage Publications.

Deci, E.L., \& Ryan, R.M. (1985). Intrinsic motivation and selfdetermination in human behavior. New York: Springer.

Davis, K., \& Newstrom, W. (2007). El comportamiento humano en el trabajo. Comportamiento organizacional. México: Mc. Graw- Hill.

El Economista. (2016). Tres de cada cuatro trabajadores están satisfechos con su empleo, según randstad. Retrieved from http://www.eleconomista.es/economia/noticias/7941648/11/16/Tresde-cada-cuatro-trabajadores-estan-satisfechos-con-su-empleo-segun-randstad.html

Ergenli, A., Ari, G. \& Metin, S. (2007). Psychological empowerment and its relationship to trust in immediate managers. Journal of Business Research, 60, 41-49.

Garmendia, J. A., \& Parra, F. (1993): Sociología Industrial y de los recursos humanos. Madrid, España: Taurus.

Ghazzawi, I., \& Smith, Y.S. (2009). Crafting the whole employee: job satisfaction, job commitment, and faith. The business review, 12(2), 300-309.

Gibson, J.L., Ivancevich, J.M., Donnelly, J.H., \& Konopaske, R. (2013). Organizaciones. Comportamiento, estructura y procesos. México: McGraw Hill.

Hackman J.R., \& Oldham G.R. (1975) Motivation through the design of work: testing of a theory. Organizational Behavior and Human Performance 11, 250-279.

Hair, J. F., Hult, G. T. M., Ringle, C. M., \& Sarstedt, M. (2017). A Primer on Partial Least Squares Structural Equation Modeling. 2nd Ed. Thousand Oaks: Sage.

Harpaz, I. (1983). Job satisfaction: Theoretical perspectives and a longitudinal analysis. Nueva York, USA: Libra Publishers.

Hayes, A. F. (2013). Introduction to Mediation, Moderation, and Conditional Process Analysis: A Regression-Based Approach. New York, NY: The Guilford Press.

Hernández, R., Fernández, C., \& Baptista, P. (2016). Metodología de la investigación. México, D.F.: McGraw Hill Interamericana Editores.

Jaimez, M. J. \& Díaz, F. (2011). El empowerment organizacional: el inicio de una gestión saludable en el trabajo. Revista de Trabajo y Seguridad Social. Recursos Humanos, 344, $209-232$.

Kanter, R. M. (1977). Men and women of the corporation. New York: Basic Books.

Kanter R. M. (1993). Men and Women of the Corporation. New York: Basic Books.

La Jornada (2014). En México, 80\% de los trabajadores están satisfechos con su trabajo, según encuesta. Retrieved from http://www.jornada.unam.mx/2014/08/03/politica/017n1pol

Laschinger, H., Finegan, J., Shamian, J. \& Wilk, P. (2003). Workplace empowerment as a predictor of nurse burnout in restructured healthcare settings. Longwoods Review, 1(3), 2-11.

Le Bossé, Y. \& Dufort, F. (2002). El empoderamiento de las personas y comunidades: otra forma de intervenir. Agir au coeur des communautés: La psychologie communitaire et le changement social, 8, 75-115.

Locke, E.A. (1976). The nature and causes of job satisfaction. Chicago: Dunnette. Handbook of Industrial and Organizational Psychology, Rand McNally, Chicago, IL, 1297-349.

Marvel, M., Rodríguez, C. \& Núñez, M. (2011). La productividad desde una perspectiva humana: dimensiones y factores. Intangible Capital, 7(2), 549-584.

Meilá, J.L. \& Peiró, J.M. (1998). Cuestionario de satisfacción laboral S20/23. Psicología de la seguridad. Universidad de Valencia.

Mendoza, J., \& Garza, J. B. (2009). La medición en el proceso de investigación científica: Evaluación de validez de contenido y confiabilidad (Measurement in the scientific research process: Content validity and reliability evaluation).

Meyer, J. P. \& Allen, N. J. (1991). A three-component conceptualization of organizational commitment. Human Resource Management Review, 1, 61-89.

O'Brien, J. L. (2010). Structural empowerment, psychological empowerment and burnout in registered staff nurses working in outpatient dialysis centers (Doctoral dissertation, Rutgers UniversityGraduate School-Newark). 
Padilla, L. E., Jiménez, L., \& Ramírez, M. D. (2008). La satisfacción con el trabajo académico: Motivaciones y condiciones del entorno institucional que la afectan. El caso de una universidad pública estatal. Revista mexicana de investigación educativa, 13(38), 843-864.

Partida, A., Blanco, M., Osorio, J., \& Jardines, F. J. (2013). El burnout y su impacto en los docentes de áreas administrativas y contables en universidades públicas. Primer Congreso Internacional de Investigación Educativa RIE-UANL.

Pearson, L.C., \& Moomaw, W. (2005). The relationship between teacher autonomy and stress, work satisfaction, empowerment, and professionalism. Educational Research Quartely, 29(1), 38-54.

Peterson, N.A. \& Speer, P. (2000). Linking organizational characteristics to psychological empowerment: Contextual issues in empowerment theory. Administration in Social Work, 24(4), 39-58.

Rabolini, N. M. (2009). Técnicas de muestreo y determinación del tamaño de la muestra en investigación cuantitativa. Revista argentina de humanidades y ciencias sociales, 2.

Ramírez, A., \& Benítez, J. (2012). Satisfacción laboral en una institución educativa de nivel superior del Estado de México. Acta Universitaria, 22(8), 33-42.

Rico-Picó, J., Peinado-Estévez, Á., Salvador-Ruiz, M., \& González-Fuentes, F. (2016). Empowerment, satisfacción laboral e identificación organizacional en funcionarios andaluces. ReiDoCrea, 5(2), 33-39.

Rositas, J., \& Mendoza, J. (2009). Estrategias, competencias, calidad y compensaciones y su grado de presencia e impacto en la competitividad de empresas del área metropolitana de Monterrey. Trabajo presentado en 1er. Congreso Internacional de Investigadores en Competitividad y Negocios de la Universidad Autónoma de Tamaulipas. Nuevo Laredo, Tam., México.

Sánchez, F. (1998). Psicología social. Madrid: McGraw-Hill.

Sarwar, A., \& Khalid, A. (2011). Impact of employee empowerment on employee's job satisfaction and commitment with the organization. Interdisciplinary Journal of Contemporary Research in Business, 3(2), 664.

SECTUR. (2017). Anuario estadístico y geográfico de Nuevo León 2017. Retrieved from http://www.datatur.sectur.gob.mx/ITxEF_Docs/NL_ANUARIO_PDF.pdf

Segovia, A. (2014). El liderazgo, la compensación variable, el empowerment psicológico y su impacto en la efectividad del empleado: un enfoque de modelación mediante ecuaciones estructurales (Doctoral dissertation, Universidad Autónoma de Nuevo León).

Seibert, S.E., Wang, G., \& Courtright, S.H. (2011). Antecedents and consequences or psychological and team empowerment in organizations: A meta-analytic review. Journal of Applied Psychology, 96(5), 981-1003.

Shahzad, K., Hussain, S., Bashir, S., Chishti, A., \& Nasir, Z.M. (2011). Organizational environment, job satisfaction and career growth opportunities: a link to employee turnover intentions in Public Sector of Pakistan. Interdisciplinary Journal of Contemporary Research in Business, 2(9), 45-56.

Spector, P. E. (1997). Job Satisfaction: Application, assessment, causes and consequences. Thousand Oaks, USA: Sage Publications Inc.

Spreitzer, G. M. (1995). Psychological Empowerment in the Workplace: Dimensions, Measurement, and Validation. The Academy of Management Journal, 38(5), 1442-1465.

Thomas, K. \& Velthouse, B. (1990). Cognitive Elements of Empowerment: An "Interpretive" Model of Intrinsic Task Motivation. Academy of Management Review, 15, 666-681.

UANL. (2018). Directorio de planteles de nivel medio superior (Nuevo León). Proceso de Asignación de Espacios en la Educación Media Superior del Estado de Nuevo León 2018. Retrieved from http://www.uanl.mx/alumnos/convocatorias/registro-de-aspirantes-preparatoria-en-modalidadpresencial.html

Wang, G., \& Lee, P. D. (2009). Psychological empowerment and job satisfaction: An analysis of interactive effects. Group \& Organization Management, 34(3), 271-296.

Whetten, D. A. (1989). What constitutes a theoretical contribution? Academy of management review, 14(4), 490-495. 